\title{
INVESTIGATIONS ON THE AGRONOMIC AND SPORTS FIELD CHARACTERISTICS OF SOME TURF ALTERNATIVES CUT AT DIFFERENT HEIGHTS IN A MEDITERRANEAN ENVIRONMENT
}

\author{
Ali SALMAN ${ }^{*}$, Behcet KIR ${ }^{2}$, Riza AVCIOGLU², Sukru Sezgi OZKAN² \\ ${ }^{1}$ Ege University, Vocational School of Bayindir, Izmir, TURKEY \\ ${ }^{2}$ Ege University, Faculty of Agriculture, Department of Field Crops, Izmir, TURKEY \\ *Corresponding author: ali.salman@ege.edu.tr
}

Received: 12.03 .2019

\begin{abstract}
In an attempt to investigate the turf alternatives most adaptable to sports fields under Mediterranean ecology, three different turf alternatives (1- Tall Fescue 100\%, 2- Tall Fescue 60\% + Perennial Rye Grass 40\% and 3Traditional Cool Season Sports Turf Mixture: Perennial Rye Grass 50\%, Creeping Red Fescue 20\%, Chewing's Red Fescue 10\%, Sheep Fescue 10\%, Kentucky Blue Grass 10\%) under three vertical cutting height regimes $(12-22-32 \mathrm{~mm})$ were tested in the turf experimental fields of Ege University Bayindir Vocational School, Izmir/Turkey in 2012-2014. Turf color and cover were determined to evaluate the adaptability of selected turf alternatives in the experiment. Ball rebound, ball roll, and evenness were also measured to identify the playing quality parameters of these turf stands in the same experimental plots. The overall results obtained from the experiment revealed that statistically significant differences occurred among the turf alternatives and different cutting heights. However, pure tall fescue turf and the $60 \%$ tall fescue + 40\% perennial rye grass turf mixture performed better than the traditional mixture. Although significant differences were recorded among the mowing heights, pure tall fescue turf displayed better performance compared to traditional cool season sports turf mixture.
\end{abstract}

Keywords: Ball rebound, ball roll, evenness, turf color, turf cover

\section{INTRODUCTION}

Among the cool season turf grasses, tall fescue shows the best adaptation to Mediterranean environment. Tall fescue (Festuca arundinacea Schreb.) is regarded as the most tolerant species against the high temperature, drought and salinity stresses among cool season turf species of Gramineae (Huang and Gao, 2000). Many researchers appreciate their special characteristics such as deep roots, shadow adaptation, wear resistance and weed competition (Salman et al., 2011a), however, its use in sports turf is quite limited both because of reduced tolerance to low mowing height and partial withering of leaves during winter period. Recently, a number of dwarftype varieties suitable for the construction of sports turf areas have been released and management practices associated with mowing height and frequency as well as nutrient impacts, turf and sports field playing quality should be reconsidered (Grossi et al., 2004).

In the modern world, in addition to the characteristics of the quality in sports turf, it is an important part of the turf researches in the tests related to the playing quality, unless a particular experimental treatment or new product can be shown to enhance an enjoyment or safety of players during a game (Baker and Canaway, 1993). There has also been an increasing interest in the using of performance standards, including measurement of playing quality, in another word "sports field quality" (Lulli et al., 2004).

The main objectives of sports turf research are to provide a playground that can be managed with an economical and acceptable budget but we must try to produce a surface that minimizes the risk of injury and allows maximum enjoying a game of player (Baker and Canaway, 1993). In researches on sports turf made in athletic fields, the quality and security of the playing area constitute two important characteristics (Bell at al., 1985). Some of the most important characters in the interaction between ball and surface are ball rebound and ball roll. In addition, the players are also sensitive to cover of the grass and the evenness of the game surface which is significant in bumps and hollows. (Baker and Canaway, 1993).

The aim of this study was to evaluate the turf quality and sports field playing characteristics of a dwarf-type tall fescue cultivar sown as a pure stand or in mixture with perennial ryegrass under different mowing height 
practices and additionally to compare its performance with the traditional sports turf mixture alternative.

\section{MATERIALS AND METHODS}

The trial was conducted in 2013 -2014 and started in November on the experimental area located in Bayindir Vocational School, Ege University, Izmir, Turkey. Typical Mediterranean climate was observed during the experimental years and the long term average, temperature was $16,6{ }^{\circ} \mathrm{C}$ and precipitation was $623,8 \mathrm{~mm}$ with irregular distribution among months. The soil of experimental area was loamy sand textured favorable as

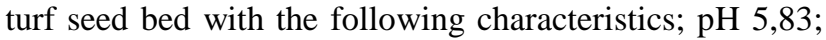
total $\mathrm{CaCO}_{3}$ 0,82 \%; total nitrogen (Kjeldahl) 0,092\%; organic matter 2,27 ppm; available phosphorus 2,54 ppm: exchangeable potassium $40 \mathrm{ppm}$. At the beginning of September, the seedbed was made by disrupting a vegetable fellow with a moldboard ploughed at $25 \mathrm{~cm}$ deep. Before this preparation, the experimental plots were equipped with a permanent pipeline system using rotary sprinklers. During the summer season, supplemental irrigation has been carried out when necessary to prevent visual wilt of the turf by sprinkling. In the first week of November of the year 2012, nitrogen, phosphorus and potassium fertilizers were applied at a rate of $75 \mathrm{~kg} \mathrm{ha}^{-1} \mathrm{~N}$, $50 \mathrm{~kg} \mathrm{ha}^{-1} \mathrm{P}_{2} \mathrm{O}_{5}$ and $50 \mathrm{~kg} \mathrm{ha}^{-1} \mathrm{~K}_{2} \mathrm{O}$, respectively, before seeding and levelling the soil with a cultivator and harrow.

The experiment was conducted in a factorial randomized complete block design with four replications. Three turf grass alternatives (\%100 Festuca arundinacea, $\% 60$ Festuca arundinacea +\%40 Lolium perenne and Traditional cool season sports turf mixture; $50 \%$ Lolium perenne, 20\% Festuca rubra var. rubra, 10\% Festuca ovina, 10\% Festuca rubra commutata, 10\% Poa pratensis) were tested in trial. Plot size was $2 \mathrm{~m}$ wide by $12 \mathrm{~m}$ long and no bare soil corridor was maintained between plots. As an experimental factor, horizontal mowing practices in three different cutting heights (12 $\mathrm{mm}, 22 \mathrm{~mm}$ and $32 \mathrm{~mm}$ ) were performed on the turf cover. The first mowing was made by a vertical mover (Husqvarna R52S) 6 weeks after sowing. Invading weeds were removed during the establishment period by hand when necessary. However, after the turfs were fully established the area, weeds were allowed to invade as the competition evolved better with grass cultivars.

The following measurements were made during the trial. Turf color and cover were assessed by a visual score based on a 1-9 scale, as recommended in the National Turfgrass Evaluation Program in the USA (Morris and Sherman, 1998). Rating scale used $1=$ poorest and $9=$ highest quality. Observations and scoring were maintained on a monthly basis, and summarized as year average. The following soccer playing characteristics were measured on the plots. Ball rebound (Football, FIFA playing quality standard ball size 5 , inflated to 0,9 bar released from a height of $2 \mathrm{~m}$.) data were given as $\mathrm{cm}$, ball roll $(\mathrm{cm})$ and evenness $(\mathrm{mm})$ were measured as FIFA standards (FIFA, 2005) with using "Club Set" of Deltec Metaal. All data except turf color and cover were analyzed statistically by using TOTEMSTAT Statistical program (Acikgoz et al., 2004) and significant means were compared by the LSD test at $5 \%$ probability level as described by Steel and Torrie (1980). Statistical analysis based on the two years averages results.

\section{RESULTS AND DISCUSSION}

Turf Color: The average color score of $32 \mathrm{~mm}$ mowing height was higher than other treatments except traditional cool season sports turf mixture, whereas average color score of $22 \mathrm{~mm}$ mowing height ranked second among others (Table 1). At $12 \mathrm{~mm}$ and $22 \mathrm{~mm}$ mowing heights, the color was lighter (7.01 and 7.13, respectively) compared to the $32 \mathrm{~mm}$ cutting height. The $60 \%$ tall fescue $+40 \%$ perennial ryegrass mixture color scores was ranked first and traditional mixture has also far better color score than pure tall fescue.

The findings of the color property showed that the $60 \%$ Festuca arundinacea $+40 \%$ Lolium perenne grass mixture under $32 \mathrm{~mm}$ mowing height had the highest color score in summer. Festuca arundinacea, constituting $60 \%$ of the mixture, is well known for its dark bluish green color (Beard, 1973) and Lolium perenne with its world-famous bright green color (Schildrick, 1984; Volterani and Magni, 2004) are widely used turf grasses. These two species are balanced by complementing each other and can achieve color quality in average scores of 7.00 or more in almost every season (Bilgili and Acikgoz, 2005; Avcioglu et al., 2013). Since the types of turf species tested for color performance are cool season grasses and due to the poor stress tolerance of sports field mixture and Lolium perenne other than Festuca arundinacea which can adapt well to the Mediterranean ecologies, the growth and development rate of mixture and Lolium were reduced. Therefore, the green color density and brightness of the plants and the canopy quality have also decreased due to the chlorophyll loses by the climatic limitations in leaf production. So the color quality of the sports field mixture was the poorest among others, particularly during summer season.

When the mowing height decreases, the photosynthetic surfaces (green leaves and stems) producing biomass and chlorophyll in plants also decrease (Beyrouty et al., 1991), resulting in color quality reduction. These phenomena were generally observed in summer in our experimental plots (Avcioglu, 1997). Turf color, which is indicative of the healthy development of turf crops and the ratio of high photosynthetic activity, is a convenient feature for evaluating the turfs (Martiniello, 2005). For this reason, the green color tone increases rapidly in the plants that are able to perform optimum growth and development, which is especially important for turf plants (Beard, 1973; Avcioglu, 1997). Our results regarding the turf color were confirmed by Volterrani and Magni (2004), Bilgili and Acikgoz (2011)'s findings.

Turf Cover: The results of cover trait of turf alternatives in the scope of three different mowing heights were given in Table 1. Cover rates were changed significantly throughout the seasons and increased as the 
mowing height increased. According to the visual evaluations, the pure tall fescue turf showed full score (9.00) or nearly the same cover rate scores in almost all seasons. Tall fescue and perennial ryegrass mixture had also similar performance with pure tall fescue, whereas the traditional mixture was not successful with a very limited cover rates in all mowing heights during summer season. The values decreased drastically for traditional mixture in late summer and reduced to almost minimum average score (5.87) in $32 \mathrm{~mm}$ mowing height (Demiroglu et al., 2010; Salman et al., 2011b, Uzun and Bilgili, 2011). All species in the traditional mixture did not have any adaptive capacity to the hot and dry conditions was observed (Hessayon, 1982; Salisbury and Ross, 1992; Gul and Avcioglu, 1997; Kir et al., 2010), so they were far behind the other turf options in terms of growth and development and could not establish a successful turf cover.

Table 1. Color and cover traits of some turf alternatives cut at different heights

\begin{tabular}{|c|c|c|c|c|c|c|c|c|c|c|c|}
\hline \multirow{2}{*}{$\begin{array}{c}\text { Turf } \\
\text { Alternativ } \\
\text { es }\end{array}$} & \multirow{2}{*}{$\begin{array}{l}\text { Mowin } \\
\text { g } \\
\text { Height } \\
\text { s (mm) }\end{array}$} & \multicolumn{5}{|c|}{ Color (1-9) } & \multicolumn{5}{|c|}{ Cover (1-9) } \\
\hline & & $\begin{array}{c}\text { Winte } \\
\mathbf{r}\end{array}$ & $\begin{array}{l}\text { Sprin } \\
\mathrm{g}\end{array}$ & $\begin{array}{c}\text { Summe } \\
\mathbf{r}\end{array}$ & $\underset{n}{\text { Autum }}$ & $\underset{\mathbf{n}}{\text { Mea }}$ & $\begin{array}{c}\text { Winte } \\
\mathbf{r}\end{array}$ & $\begin{array}{l}\text { Sprin } \\
\mathbf{g}\end{array}$ & $\begin{array}{c}\text { Summe } \\
\mathbf{r}\end{array}$ & $\underset{\mathbf{n}}{\text { Autum }}$ & $\begin{array}{c}\text { Mea } \\
\mathbf{n}\end{array}$ \\
\hline Tall & 12 & 5,81 & 6,08 & 6,13 & 6,13 & 6,03 & 9,00 & 9,00 & 8,92 & 9,00 & 8,98 \\
\hline Fescue & 22 & 5,95 & 6,42 & 6,45 & 6,05 & 6,22 & 9,00 & 9,00 & 8,92 & 9,00 & 8,98 \\
\hline $100 \%$ & 32 & 6,90 & 7,08 & 7,25 & 7,05 & 7,07 & 9,00 & 9,00 & 8,97 & 9,00 & 8,99 \\
\hline \multicolumn{2}{|c|}{ Mean } & 6,22 & 6,52 & 6,61 & 6,41 & 6,44 & 9,00 & 9,00 & 8,93 & 9,00 & 8,98 \\
\hline \multirow{3}{*}{$\begin{array}{c}\text { Tall } \\
\text { Fescue } \\
60 \%+ \\
\text { Ryegrass } \\
40 \%\end{array}$} & 12 & 7,86 & 7,92 & 8,12 & 7,80 & 7,92 & 8,18 & 8,11 & 8,29 & 8,60 & 8,30 \\
\hline & 22 & 7,83 & 8,10 & 8,33 & 8,09 & 8,09 & 8,56 & 8,74 & 8,28 & 8,38 & 8,49 \\
\hline & 32 & 8,05 & 8,22 & 8,46 & 8,16 & 8,22 & 8,95 & 8,90 & 8,30 & 8,43 & 8,65 \\
\hline \multicolumn{2}{|c|}{ Mean } & 7,91 & 8,08 & 8,30 & 8,02 & 8,08 & 8,56 & 8,58 & 8,29 & 8,47 & 8,48 \\
\hline \multirow{3}{*}{$\begin{array}{l}\text { Traditiona } \\
\text { I Mixture }\end{array}$} & 12 & 7,33 & 7,22 & 6,70 & 7,00 & 7,06 & 6,63 & 7,83 & 5,94 & 7,28 & 6,92 \\
\hline & 22 & 7,23 & 7,30 & 6,72 & 7,10 & 7,09 & 6,76 & 7,12 & 5,98 & 7,28 & 6,78 \\
\hline & 32 & 6,93 & 6,63 & 5,74 & 7,38 & 6,67 & 7,02 & 6,89 & 5,87 & 7,73 & 6,88 \\
\hline \multicolumn{2}{|c|}{ Mean } & 7,16 & 7,05 & 6,39 & 7,16 & 6,94 & 6,80 & 6,28 & 5,93 & 7,43 & 6,86 \\
\hline \multirow{3}{*}{$\begin{array}{c}\text { General } \\
\text { Mean }\end{array}$} & 12 & 7,00 & 7,07 & 6,98 & 6,98 & 7,01 & 7,94 & 8,31 & 7,72 & 8,29 & 8,06 \\
\hline & 22 & 7,00 & 7,27 & 7,17 & 7,08 & 7,13 & 8,11 & 8,29 & 7,73 & 8,22 & 8,08 \\
\hline & 32 & 7,29 & 7,31 & 7,15 & 7,53 & 7,32 & 8,32 & 8,26 & 7,71 & 8,39 & 8,17 \\
\hline \multicolumn{2}{|c|}{ Mean } & 7,10 & 7,22 & 7,10 & 7,20 & 7,15 & 8,12 & 8,29 & 7,72 & 8,30 & 8,11 \\
\hline
\end{tabular}

In this part of the study, Festuca arundinacea turf, having the highest covering score, was the most successful turf option in terms of cover feature in addition to full adaptability to Mediterranean environment and due to its morphological trait of having relatively large leaf blades (Volterani and Magni, 2004). The Traditional mixture turf option consisting of cool season grasses like \%50 Lolium perenne $+\% 20$ Festuca rubra rubra $+\% 10$ Festuca rubra commutata $+\% 10$ Festuca ovina $+\% 10$ Poa pratensis, which are not adoptable to the warm climates, provided that they could not also adapt to the Mediterranean ecology and they were far behind the other turf options in terms of growth and development and couldn't perform a successful turf cover (Hessayon, 1982; Salisbury and Ross, 1992; Gul and Avcioglu, 1997).

In all turf options tested, it was also observed that the cover scores decreased as the mowing height reduced, especially in traditional turf mixture, whereas Festuca arundinacea and \%60 Festuca arundinacea $+40 \%$ Lolium perenne mixture turf options were not adversely affected by this practices. The traditional mixture rapidly weakened and the cover rates decreased due to the crop losses by the seasonal killings. Gul and Avcioglu (1997), Harivandi et al. (2008) and Demiroglu et al. (2010) also reported findings consistent with our results.

Ball Rebound: As pointed out previously, the ball rebound character is expressed as the ratio of height bounced/height dropped (Table 2.) According to the results obtained in terms of ball rebound measurements and of statistical analysis; In addition to the three way and dual interactions, turf options had significant differences mainly in different seasons. In pure tall fescue and tall fescue + perennial ryegrass plots, ball rebound values were determined as in the acceptable ranges, except the traditional cool season sports turf mixture in winter, while impact of mowing heights was also significant particularly in the traditional mixture. Ball rebound values of $32 \mathrm{~mm}$ mowing height were generally lower than 12 or $22 \mathrm{~mm}$ mowing heights in all turf alternatives during spring and summer, and were over the acceptable range for tall fescue + perennial ryegrass and traditional cool season sports turf mixture almost in all mowing heights. 
Table 2. Ball rebound and ball roll traits of some turf alternatives cut at different heights

\begin{tabular}{|c|c|c|c|c|c|c|c|c|c|c|c|}
\hline \multirow{2}{*}{$\begin{array}{c}\text { Turf } \\
\text { Alternatives }\end{array}$} & \multirow{3}{*}{$\begin{array}{c}\text { Mowing } \\
\text { Heights } \\
(\mathbf{m m}) \\
12\end{array}$} & \multicolumn{5}{|c|}{ Ball Rebound (cm) } & \multicolumn{5}{|c|}{ Ball Roll (cm) } \\
\hline & & Winter & Spring & Summer & Autumn & Mean & Winter & Spring & Summer & Autumn & Mean \\
\hline \multirow{3}{*}{$\begin{array}{c}\text { Tall Fescue } \\
100 \%\end{array}$} & & 80,33 & 72,33 & 93,00 & 74,33 & 80,00 & 686,67 & 708,50 & 612,50 & 783,33 & 697,75 \\
\hline & 22 & 77,17 & 73,33 & 82,17 & 79,67 & 78,08 & 671,50 & 686,17 & 582,50 & 751,67 & 672,96 \\
\hline & 32 & 64,50 & 86,83 & 74,33 & 80,33 & 76,50 & 606,17 & 641,67 & 562,33 & 662,50 & 618,17 \\
\hline \multicolumn{2}{|c|}{ Mean } & 74,00 & 77,50 & 83,17 & 78,11 & 78,19 & 654,78 & 678,78 & 585,78 & 732,50 & 662,96 \\
\hline \multirow{3}{*}{$\begin{array}{c}\text { Tall Fescue } \\
60 \%+ \\
\text { Ryegrass } \\
40 \%\end{array}$} & 12 & 96,33 & 86,50 & 88,33 & 88,83 & 90,00 & 674,83 & 709,00 & 639,50 & 786,67 & 702,50 \\
\hline & 22 & 78,67 & 73,50 & 74,00 & 81,83 & 77,00 & 662,50 & 688,50 & 602,33 & 800,00 & 688,33 \\
\hline & 32 & 69,00 & 63,50 & 70,17 & 73,33 & 69,00 & 613,67 & 601,67 & 590,17 & 730,83 & 634,08 \\
\hline \multicolumn{2}{|c|}{ Mean } & 81,33 & 74,50 & $\mathbf{7 7 , 5 0}$ & 81,33 & 78,67 & 650,33 & 666,36 & 610,67 & 772,50 & 674,97 \\
\hline \multirow{3}{*}{$\begin{array}{l}\text { Traditional } \\
\text { Mixture }\end{array}$} & 12 & 97,83 & 92,00 & 106,00 & 95,33 & 97,79 & 759,83 & 720,50 & 731,17 & 805,83 & 754,33 \\
\hline & 22 & 88,67 & 89,17 & 98,67 & 86,83 & 90,83 & 725,50 & 712,00 & 695,00 & 805,83 & 734,58 \\
\hline & 32 & 86,50 & 83,17 & 90,50 & 81,67 & 85,46 & 704,33 & 681,00 & 706,83 & 713,33 & 701,38 \\
\hline \multicolumn{2}{|c|}{ Mean } & 91,00 & 88,11 & 98,39 & 87,94 & 91,36 & 729,89 & 704,50 & 711,00 & 775,00 & 730,10 \\
\hline \multirow{3}{*}{$\begin{array}{l}\text { General } \\
\text { Mean }\end{array}$} & 12 & 91,50 & 83,61 & 95,78 & 86,17 & 89,26 & 707,11 & 712,67 & 661,06 & 791,94 & 718,19 \\
\hline & 22 & 81,50 & 78,67 & 84,94 & 82,78 & 91,97 & 686,50 & 695,56 & 626,61 & 785,83 & 698,63 \\
\hline & 32 & 73,33 & 77,83 & 78,33 & 78,44 & 76,99 & 641,39 & 641,44 & 619,78 & 702,22 & 651,21 \\
\hline \multicolumn{2}{|c|}{ Mean } & 82,11 & 80,04 & 86,35 & 82,46 & 82,74 & 678,33 & 683,22 & 635,81 & 760,00 & 689,34 \\
\hline \multicolumn{2}{|c|}{ LSD (\%5): } & $\begin{array}{l}\text { TA: }( \\
\text { TAx }\end{array}$ & $\begin{array}{l}4 \mathrm{MH}:( \\
0,09 \mathrm{M}\end{array}$ & $\begin{array}{l}4 \text { TA: } 0, \\
\text { SS: } 0,097\end{array}$ & $\begin{array}{l}\text { TAxMH } \\
\text { AMHxS: }\end{array}$ & 15 & \multicolumn{5}{|c|}{$\begin{array}{l}\text { TA: } 1,56 \text { MH: } 1,56 \text { S: } 1,80 \text { TAxMH: 2,70 } \\
\text { TAxS: } 3,12 \text { MHxS: } 3,12 \text { TAxMHxS: 5,41 }\end{array}$} \\
\hline
\end{tabular}

TA: Turf Alternatives, MH: Mowing Height, S: Season

Since the ball bounce height (rebound) feature is significant and required to be within certain boundary ranges for playing process, Baker and Canaway (1993) explain that these boundaries are determined in detail in the UK, but in other European countries, as a rule, ball rebound feature is defined under international borders in FIFA regulations (FIFA, 2005). Ball rebound feature has become a dependable and more easily measurable criterion since it is determined to be the highest point (60$85 \mathrm{~cm}$ range) at which the ball can rise after the jump in FIFA standards. The turf tester (Deltec Club Set) was used in this study for ball rebound measurements. Researchers working on this subject (FIFA, 2009b; Saunders et al., 2011) found that soil dryness, stiffness and weakness of turf cover or lack of vegetation, precipitation or irrigation conditions and mowing heights were effective factors on this trait. For example, ball rebound height of 60-65 cm can be measured in a grassy turf with strong textures, densely covered and sufficiently wet soil, whereas in a medium cared and weakly covered turf stand with heavy soil may have a measurement of 80-95 or even $100 \mathrm{~cm}$ height acceptable quality (Grossi et al., 2004).

The data revealed that the ball rebound values reached the highest values in almost every season, being highest in the traditional mixture during summer period. Since the heights within the range of $60-85 \mathrm{~cm}$ ball rebounds in ideal turf stands can be measured, ball rebound values in our turf alternatives and especially in the traditional mixture were higher than the standards. The traditional mixture turf alternative composed of turf species not adaptable to hot and dry conditions of Mediterranean climate (Salisbury and Ross, 1992, Watschke et al., 1992), couldn't perform a successful growth and development resulting in a weak turf cover. However, Festuca arundinacea and its mixture displayed that the ball rebound values was in acceptable ranges due to the dense grass cover and favorable texture.

Ball Roll: Ball roll character is basically the function of rolling and rolling resistance which is regarded as a force acting at the point of contact between the ball and surface whose direction is the inverse of the direction of movement and therefore causes the ball to slow down while moving along the surface and generally expressed in terms of distance rolling by the ball indirectly (Baker and Bell, 1986). Ball roll measurements displayed limited overall values in all treatments (Table 2). Although significant differences of ball roll values were recorded between research factors and their interactions, these values, having limited variations, were within the standard ranges. The ball roll distances reduced as the mowing height increased and higher distances were recorded in pure tall fescue or tall fescue + perennial ryegrass mixed sowings. These distances were also higher in spring and summer seasons compared to winter, especially in terms of traditional mixture.

Since the ball roll distance trait is important in terms of the speed of the game and the dominance of the players in football or similar sports playing process, this feature is also required to be within certain boundary ranges (Baker and Canaway, 1993). These limits were initially determined as 4-14 $\mathrm{m}$ in UK, but the ideal of 4-10 $\mathrm{m}$ range was also adopted by FIFA's international studies (FIFA, 2009a).

Orchard (2002) and FIFA (2009b) revealed that soil dryness and grass cover weakness or lack of vegetation, soil moisture status and especially mowing heights were the most important factors affecting the ball roll distances. Grossi et al. (2004) and Miller (2004) pointed out that a $4.00 \mathrm{~m}$ ball rolling distance can be measured in a grassy area with strong texture and high stubble, and sufficiently 
moist soil whereas this value can increase to 8.00 meters in grass clippings with short stubble and deep mowing treatments. The $100 \%$ Festuca arundinacea and $60 \%$ Festuca arundinacea $+40 \%$ Lolium perenne mix, which have had satisfactory performance in many aspects, were generally observed to have Ball Roll Distances between their standard limits in all seasons. The ball roll distance values, except for some deviations, generally increased to the negative values in the hot and drought stress conditions of summer season and in all other applications. Results also showed that decreasing height of mowing resulted in higher ball roll distances due to the shorter grass existence in turf covers (Volteranni and Magni, 2004; Kir et al., 2014; Ozkan et al., 2014).

Evenness: According to the results of the statistical analysis applied to the evenness values, it was shown that the turf alternatives reveal significantly different performances at differing levels, and that these evenness levels were more variable than the values in different mowing heights and seasons (Table 3). Evenness; is an important measure that reveals the depth of the tiny ridges and trenches below the turf cover and the soil surface in millimeters, and the level of the environment in which the athletes in the sports areas are prevented from falling when they make sliding, running and turning movements (Orchard, 2002). According to the English system, this standard is $8-10 \mathrm{~mm}$ and in FIFA standards, it is $4-11 \mathrm{~mm}$ or 4-8 $\mathrm{mm}$ depending on the condition of the sports field (Baker and Canaway, 1993; FIFA, 2005). In terms of evenness values, it was determined that $100 \%$ Festuca arundinacea and 60\% Festuca arundinacea $+40 \%$ Lolium perenne mixture had lower but within the standards of evenness values. It was understood that the evenness values increased especially in the traditional cool season sports turf mixture as the turf cover became weaker. From the point of the evenness, despite the significant differences between them, the average evenness values of all turf alternatives in different mowing heights and seasons were located between the lower and upper limits of the standards. It was concluded that a dependable suggestion couldn't be produced in order to demonstrate what kind of performance had the turf alternatives according to seasons and years. In order to perform an effective analysis, it was also suggested that the treatments would be more accurate to measure by providing simulations of sports activities in the plots and creating traffic effects in its dose (Lulli et al., 2004; Martin, 2007).

Table 3. Evenness trait of some turf alternatives cut at different heights

\begin{tabular}{|c|c|c|c|c|c|c|}
\hline \multirow{2}{*}{ Turf Alternatives } & \multirow{2}{*}{$\begin{array}{c}\text { Mowing Heights } \\
\text { (mm) }\end{array}$} & \multicolumn{5}{|c|}{ Evenness (mm) } \\
\hline & & Winter & Spring & Summer & Autumn & Mean \\
\hline \multirow{3}{*}{ Tall Fescue $100 \%$} & 12 & 4,15 & 3,93 & 3,68 & 4,08 & 3,96 \\
\hline & 22 & 3,87 & 3,93 & 3,52 & 3,98 & $\mathbf{3 , 8 3}$ \\
\hline & 32 & 3,72 & 3,57 & 3,65 & 3,67 & 3,65 \\
\hline \multicolumn{2}{|l|}{ Mean } & 3,91 & 3,81 & 3,62 & 3,91 & 3,81 \\
\hline \multirow{3}{*}{$\begin{array}{c}\text { Tall Fescue } 60 \%+ \\
\text { Ryegrass } 40 \%\end{array}$} & 12 & 4,72 & 5,15 & 4,02 & 4,15 & 4,51 \\
\hline & 22 & 4,67 & 4,45 & 3,92 & 4,10 & 4,28 \\
\hline & 32 & 4,07 & 4,57 & 3,98 & 3,57 & 4,05 \\
\hline \multicolumn{2}{|l|}{ Mean } & 4,48 & 4,72 & 3,97 & 3,94 & 4,28 \\
\hline \multirow{3}{*}{ Traditional Mixture } & 12 & 6,65 & 6,12 & 4,87 & 4,70 & 5,58 \\
\hline & 22 & 6,43 & 6,27 & 4,60 & 4,98 & 5,57 \\
\hline & 32 & 6,08 & 5,50 & 4,38 & 4,85 & 5,20 \\
\hline \multicolumn{2}{|l|}{ Mean } & 6,39 & 5,96 & 4,62 & 4,84 & 5,45 \\
\hline \multirow{3}{*}{ General Mean } & 12 & 5,17 & 5,07 & 4,19 & 4,31 & 4,68 \\
\hline & 22 & 4,99 & 4,88 & 4,01 & 4,36 & 4,56 \\
\hline & 32 & 4,62 & 4,54 & 4,01 & 4,03 & 4,30 \\
\hline \multicolumn{2}{|l|}{ Mean } & 4,93 & $\mathbf{4 , 8 3}$ & 4,07 & 4,23 & 4,51 \\
\hline \multicolumn{2}{|c|}{ LSD (\%5): } & & $0,09 \mathrm{~S}$ & $\begin{array}{l}\text { TAxMH: } \\
\text { xMHxS: }\end{array}$ & S: 0,19 & 0,19 \\
\hline
\end{tabular}

TA: Turf Alternatives, MH: Mowing Height, S: Season

\section{CONCLUSION}

Overall results of the study revealed that pure Festuca arundinacea and \%60 Festuca arundinacea +\%40 Lolium perenne mixture performed far better than traditional cool season sports turf mixture under all different cutting height regimes in various seasons. Values of the color and cover traits of turf alternatives increased by increasing cutting heights, while ball rebound and ball roll values decreased. Evenness values were limitedly variable in terms of cutting heights and turf alternatives; however most of the variations were not significant, although the significant differences were meaningless being not stable in all factors.

As conclusion, we suggested that Festuca arundinacea and \%60 Festuca arundinacea + \%40 Lolium perenne mixture are the most adaptable cool season turf grass material in a Mediterranean environment compared to the traditional cool season sports turf mixture. Cutting 
practices in between $12-22 \mathrm{~mm}$ cutting heights were the best treatments in terms of visual turf quality and sports turf standards. We also concluded that these type of investigations should be directed to the actual conditions including sports activities and related stress factors.

\section{ACKNOWLEDGEMENT}

Research study (1120130) founded by The Scientific and Technological Research Council of Turkey (TUBITAK).

\section{LITERATURE CITED}

Acikgoz, N., E. Ilker and A. Gokcol, 2004. Assessment of Biological Research on the Computer. EU, TOTEM, Izmir.

Avcioglu, R. 1997. Turf Technique (Turf Establishment \& Management). Izmir. Ege University Press (In Turkish).

Avcioglu, R., B. Kir, A. Salman, S.S. Ozkan and T. Erasik, 2013. Turf quality and soccer playing characteristics of some turf alternatives mowed at different heights. In: Proceedings of the 24th International Scientific-Expert-Conference of Agriculture and Food Industry, Sarajevo, Bosnia and Herzegovina, 25-28 September 2013. Faculty of Agriculture and Food Sciences, University of Sarajevo, 2013. p. 352356.

Baker, S.W. and M.J. Bell. 1986. The playing characteristics of natural turf and synthetic turf surfaces for association football. Journal of the Sports Turf Research Institute. 62:935

Baker, S.W. and P.M. Canaway. 1993. Concepts of playing quality: criteria and measurement. International Turfgrass Society Research Journal. 20(7): 172-181.

Beard, J.B., 1973. Turfgrass Science and Culture, Englewood Cliffs, N, J. Printice Hall, London.

Bell, M.J., S.W. Baker and P.M. Canaway. 1985. Playing Quality of Sports Surfaces: A Review. Journal of the Sports Turf Research Institute, 61: 26-45.

Beyrouty, C.A., C.P. West and E.E. Gbur. 1991. Root Development of Bermudagrass and Tall Fescue as Affected by Cuting Interval and Growth Regulators. Plant and Soil. 127(1): 23-30.

Bilgili, U. and E. Acikgoz. 2005. Year-Round Nitrogen Fertilization Effects on Growth and Quality of Sports Turf Mixtures. Journal of Plant Nutrition, 28(2): 299-307.

Bilgili, U. and E. Acikgoz. 2011. Effects of slow-release fertilizers on turf quality in a turf mixture, Turkish Journal of Field Crops 16(2): 130-136.

Demiroglu, G., H. Geren, B. Kir and R. Avcioglu. 2010. Performances of some cool season turfgrass cultivars in Mediterranean environment: II. Festuca arundinaceae Schreb., Festuca ovina L., Festuca rubra spp. rubra L., Festuca rubra spp. trichophylla Gaud and Festuca rubra spp. commutata Gaud., Turkish Journal of Field Crops 15(2): 180-187.

FIFA. 2005. The FIFA quality concept for football turf. FIFA Marketing XTVAG, Grafenciuweg 2, P.O. Box 4250, Switzerland.

FIFA. 2009a. The FIFA quality concept for football turf, handbook of requirements May edition. FIFA Marketing XTVAG, Grafenciuweg 2, P.O. Box 4250, Switzerland, pp: 24.

FIFA. 2009b. The FIFA quality concept for football turf, handbook of test methods May 2009 edition. FIFA Marketing XTVAG, Grafenciuweg 2, P.O. Box 4250, Switzerland, pp: 42.

Grossi, N., M. Volterrani, S. Magni and S. Miele. 2004. Tall fescue turf quality and soccer playing characteristics as affected by moving height. Acta Hortic: 661: 319-322 DOI: 10.17660/ActaHortic.2004.661.41.

Gul, A. and R. Avcioglu. 1997. Investigations on the Suitability of Some Turfgrass Alternatives for the Coastal Parts of Ege Region and Their Performance in Various Sods, Ph. D. Thesis, Ege University, Institude of Science and Technology, Bornova-Izmir.

Harivandi, M.A., V.A. Gibeault, M.J. Henry, L. Wu, P.M. Geisel and C.L. Unruh. 2008. Turfgrass selection for the home landscape. UCANR Publications.

Hessayon, D.G. 1982. The Lawn Expert. Britannica House, Waltham Cross, Herts England.

Huang, B. and H. Gao. 2000. Root Physiological Characteristics Associated with Drought Resistance in Tall Fescue Cultivars. Crop Science. 40: 196-203.

Kir, B., R. Avcioglu, G. Demiroglu and A. Simic. 2010. Performances of some cool season turfgrass species in Mediterranean environment: I. Lolium perenne L., Festuca arundinacea Schreb., Poa pratensis L., Turkish Journal of Field Crops 15(2): 174-179

Kir, B., R. Avcioglu, A. Salman and S.S. Ozkan. 2014. Soccer Playing Characteristics of Some Soccer Fields Around Izmir/Turkey under Mediterranean Conditions, 25th International Scientific-Expert Conference of Agriculture and Food Industry, 25-27 September 2014, Book of Abstracts, Pp: 17, Cesme/Turkey.

Lulli, F., M. Volterrani, S. Magni, N. Grossi, M. Gaetani and A. Pompeiano. 2004. Evaluation of the playing characteristics of a new hybrid natural-artificial grass pitch. 1st European Turfgrass Society Conference. pp: 117-118.

Martin, D. 2007. Selecting a Lawn Grass for Oklahoma. Accessed on May 31, 2019 from http://pods.dasnr.okstate.edu/ docushare/dsweb/Get/Document-997/F-6418web.pdf

Martiniello, P. 2005. Variability of turf quality and phytocoenoses in areas of play in football grounds in Mediterranean environments. Agri. Med. 135: 209-220

Miller, G.L. 2004. Analysis of soccer field surface hardness. Acta Hortic. 661, 287-294 DOI: 10.17660/ActaHortic.2004.661.36.

Morris, K.N. and R.C. Shearman. 1998. NTEP Turfgrass Evaluation Guidelines, In NTEP Turfgrass Evaluation Workshop, Beltsville, MD, 5p.

Orchard, J. 2002. Is there a relationship between ground and climatic conditions and injuries in football. Sports Med.; 32 (7):419-432.

Ozkan, S.S., B. Kir and R. Avcioglu. 2014. Effect of mowing heights on the performances of some turf alternatives in Mediterranean ecology. 24th International Scientific-Expert Conference of Agriculture and Food Industry. pp. 337-340.

Salisbury, F. B. and C. W. Ross. 1992. Plant Physiology, Wadsworth Pub. Com., Inc., Belmont, California-USA.

Salman, A., R. Avcioglu, M. Y1lmaz and G. Demiroglu. 2011a. Performances of newly introduced Festuca arundinacea Schreb. cultivars versus Lolium perenne L. in a Mediterranean environment, Turkish Journal of Field Crops 16(2): 215-219

Salman, A., R. Avcioglu, H. Oztarhan, A.C. Cevheri and H. Okkaoglu. 2011b. Performances of Different Cool Season Turf Grasses and Some Mixtures under Mediterranean Environmental Condition. International Journal of Agriculture and Biology 13: 529-534.

Saunders, N., D. Twomey and L. Otage. 2011. Clegg hammer measures and human external landing forces: is there a relationship? International Journal of Sports Science and Engineering 5(4): 231-236. 
Schildrick, J. 1984. Turfgrass Manual, The Sports Turf Research Institute Publ., Bingley, England, 60 pp.

Steel, R.G.D., J.H. Torrie. 1980. Principles and Procedures of Statistics. A biometrical approach. 2nd edition. McGrawHill, New York, USA, pp. 20-90.

Uzun, P. and U. Bilgili. 2011. Effects of wastewater sludge on growth of perennial ryegrass (Lolium Perenne L.). Turkish Journal of Field Crops 16(2): 203-209.
Volterrani, M. and S. Magni. 2004. Species and growing media for sports turfs in Mediterranean area. Acta Hortic. 661, 359364 DOI: 10.17660/ActaHortic.2004.661.48.

Watschke, T.L. and R.E. Schmidt. 1992. Ecological aspects of turf communities. Waddington, D.V., Carrow, R.N. And Shearman, C.R. (Eds.). Turfgrass, American Society of Agronomy, Inc. Agronomy. 32: 129-174. 